\title{
Boom and Bust Cycles in Financial Markets-Causes and Cures: Multiple Contradictory Functions of Money and Collective Action Problems*
}

\author{
Tom R. Burns \\ Department of Sociology, University of Uppsala, Uppsala, Sweden \\ Email: *Tom.burns@soc.uu.se
}

How to cite this paper: Burns, T.R. (2017) Boom and Bust Cycles in Financial Markets-Causes and Cures: Multiple Contradictory Functions of Money and Collective Action Problems. Theoretical Economics Letters, 7, 914-928.

https://doi.org/10.4236/tel.2017.74062

Received: April 6, 2017

Accepted: June 13, 2017

Published: June 16, 2017

Copyright $\odot 2017$ by author and Scientific Research Publishing Inc. This work is licensed under the Creative Commons Attribution International License (CC BY 4.0).

http://creativecommons.org/licenses/by/4.0/

\begin{abstract}
The aim of this conceptualization article is to formulate propositions about: (1) systemic faults in established money and financial systems, in particular the mechanisms that make for boom-and-bust cycles; and (2) the cognitive and action factors which limit the central banks capabilities to consistently and effectively to regulate or to limit these cycles. Drawing on earlier research (our own as well as that of others), this conceptualization is presented in Section 1. Section 2 identifies a new design and institutional arrangement, which would minimize the boom-and-bust predispositions in money and financial systems. This work builds on earlier research invested in "the Chicago Plan" (from the 1930s) in addition to our own research. Section 3 considers the expected political and ideological constraints on reforming financial systems. Previously operating constraints-including Neo-liberal erosion of New Deal banking arguments and reforms-make for formidable barriers. The paper concludes that reform is necessary-if boom-and-bust cycles on the scale of those since 1929 are to be effectively regulated; but it is suggested that such reform is politically and ideologically difficult if not impossible in the short-run.
\end{abstract}

\section{Keywords \\ Coordination Problems, Contradictory Functions of Money, \\ Designs and Institutional Arrangements, Chicago Plan, \\ Political and Ideological Constraints}

\footnotetext{
*This article has been written in collaboration with Philippe DeVille (Department of Economics, Université Catholique de Louvain (UCL), Louvain-la-Neuve, Belgium) and Alberto Martinelli (Faculty of Political and Social Science, University of Milan, Milan, Italy).
} 


\section{Introduction}

This paper draws on earlier research (our own as well as that of others) on boom and bust cycles in financial markets. Section 1 identifies a few causes of such cycles and explains the limitations of central banks in consistently and effectively dealing with such cycles. Explanation is traced to the contradictory functions of money and the collective action problems of decentralized markets. Section 2, drawing on earlier work including that of "The Chicago Plan", identifies a new system design and institutional arrangement which would minimize boom-andbust predispositions in money and financial systems. Section 3 focuses on the political and ideological constraints on accomplishing such reform. In the conclusion, we stress the necessity of a new design (either the one sketched here or others), at the same time that any major reform will face substantial ideological institutions and political obstacles. In the meantime, it is argued, one should investigate and analyze new alternative system designs which would overcome the limitations of the established design.

\section{Systemic Flaws and the Boom-and-Bust Cycles of "Modern" Money and Financial Systems.}

In earlier work we argued that contemporary money and financial systems are systemically flawed-even with some of the reforms since 2007 such as the Dodd-Frank Act (2010); they are potentially highly unstable, prone, in particular, to repeated occurrences of boom-and-bust cycles [1]-[6]. The problem has a systemic source-the institutional condition that enables private, decentralized banks to create and destroy money-through credit creation and contraction. This takes place without effective coordination of the multiple banking agents in their aggregate creation and destruction of credit/money. The process also tends to be self-amplifying in that the further creation of credit/money results in higher asset values those are the target for credit/money creation, amplifying market demand for these assets and increasing their values. The rise in asset values reinforces the demand for more credit (and other monetary resources); increases in demand stimulate bank readiness to create more credit, potentially increasing their income from the credit/money creation process (unless, of course, there is a crash, which is the way credit booms typically end).

As we have shown in a socio-economic systems model [1], the credit facilitated "expansion phase" leads eventually to a critical phase of growing uncertainty and loss of confidence in the sustainability or resilience of the expansion. A wide spectrum of perceptions, indicators, financial sector and policy discourses, evoke a contraction phase-with stagnation or reduction in asset values as well as declining readiness of market agents to borrow (or inability to borrow due to asset value losses) as well as reduced readiness of banks to create more credit/money or even to sustain the existing high levels of credit. The banks try to reduce their degree of vulnerability, calling in loans and not making credit as readily available as in the expansion phase. During the uncoordinated contraction of credit, asset prices decline because of reduced availability of credit and 
the attempts to unload the assets that are declining in value. The result is to a greater or lesser extent "a bust" - often enough with considerable destruction of value and a climate of reduced confidence and even widespread pessimism.

After a contraction phase of greater or lesser duration, market and/or government actors eventually may redefine the situation and initiate a process of expansion, which sooner or later leads to another (excessive) expansion or boom, etc.

Our socio-economic systems research implied the following:

Principle I: Contemporary money and financial systems are systemically unstable as a result of the lack of coordination-in this case, of the private decentralized money creation and money destruction mechanisms through credit decision-making. Each banking agent decides on the basis of its immediate demand and level of risk-readiness, indications of anticipated asset value increases, and the expectation that credit created will be repaid according to contractual agreements.

The systemic problem is that private, decentralized banks are enabled to create and destroy money-through making loans, on the one hand, and through retracting or reducing loans, on the other hand-without effective coordination of the aggregate macroeconomic and financial consequences for the entire socio-economic system resulting from the decentralized creation and destruction of money. ${ }^{1}$ The process tends to be self-amplifying in that the creation and allocation of money/credit to a sectoral development (housing, or technology development) can result in greater asset values, often reinforcing the mobilization of further credit and other financial resources. The self-amplification process is fed by credit demand of debtors or potential debtors and bank credit supply made available during the boom phase. In a word, there is a lack of market coordination in the money creation process.

The self-amplifying process continues until there are indications of potential problems, excessive risks, related discourses, judgments and prognoses of an increasing number of experts (serving in part as a self-fulfilling prophesy [2] [7]). ${ }^{2}$ Uncertainty about the future of gains grows at the end of the expansion phase

\footnotetext{
${ }^{1}$ About the time our research on systemic instability of money and financial systems was being presented, there appeared articles by several key persons at the IMF and the Bank of England (Haldane and associates at the "Financial Stability Unit") with parallel conceptualizations of the boom and bust credit cycle [8] [9] [10]. They argued, as we did, that the financial system is inherently and systemically unstable-even with the various "fixes" dating from the New Deal (through the various destabilizing de-regulations brought about by Ronald Reagan et al.); furthermore, the 2010 reforms (e.g., Dodd-Frank Act) while constructive are insufficient. Because of the flaw in the systemic loop [1], the system will sooner or later result in crashes; their frequency and depth depending on the stringency of the regulatory system. That is, there is a systemic flaw in the design of the system. Even the most stringent fixes of the existing system-with its not fully controllable loop-will lead to boom-and-bust cycles. This network of authors have proposed entirely new systems, drawing on, among other sources, the original "Chicago Plan" from the 1930s, which would take credit-creation (money creation) away from private banks and place it in the sole hands of "the sovereign", i.e. the state [The plan was influential, much discussed but only partially influenced the New Deal banking regulatory reforms at the time].

${ }^{2}$ On the eve of the 1907 crisis, however, much of the financial system had enormous leverage-the ratio of debt to equity was 25 to 1 or more-leaving it extremely vulnerable to panic. And the panic came-under "fire-in-theatre" conditions-resulting in a major crash.
} 
(just as uncertainty often declines during the initiation of an expansive process). Under potential bubble conditions, as Dudlev [11] points out: "Uncertainty means that policymakers can never be sure about the existence, size, or persistence of an incipient asset bubble." A "tipping point" is eventually reached. According to Minsky [5], it is the proportion of marginal agents, that is, "financially frail" or vulnerable debtors, businesses, and banks in the whole population that determines the level of the tipping point, other things being equal. Moreover, according to Minsky, bubbles are less likely to grow large when there is a great deal of vulnerability in the system, which predisposes most agents to be risk-averse and/or un-credit worthy.

The lack of coordinated money creation and money destruction in the expansion/contraction cycle results in self-amplifying processes (vicious circles of positive feedback): in the expansive phase, a vicious circle of excessive money creation and value growth; and in the contraction phase, a vicious circle of excessive money contraction and asset value destruction.

Principle II: Constraints on the Central Bank's Regulation. It cannot reliably and effectively regulate the credit/money creation process (in the expansion phase) and the credit/money destruction process (in the contraction phase), because it is not cognitively and behaviorally designed to deal with "collective action problems". It may, of course, regulate the interest rate, but this may or may not be responded to appropriately by those debtors or potential debtors and/or by the banks themselves. It is a very indirect influence on market behavior; there is simply no direct control over these unstable socio-economic processes. And while the banks theoretically might self-regulate (as claimed by neo-liberal ideology), the population of banks lack a cognitive framework to determine the appropriate level of money for each agent to create - nor do they have an adequate institutional framework (for instance, with legal powers) to coordinate their responses in the aggregate whatever their cognitive bases-indeed, such an arrangement would be illegal in the USA and the EU. Still, what happens systemically depends on the aggregate consequences of the actions of banks. Of course, the banks observe what one another are doing-and obtain some degree of certainty in an uncertain, disorderly world through such observation and through mimicking one another, which is part of the problem.

A third principle refers to the contradictory purposes/functions of money which are not sufficiently taken into account in regulatory cognitive models and institutionalized strategies of correction [2] [3].

Principle III: Contradictory functions of money make it difficult for a central bank to regulate consistently and effectively, for instance to maintain stable monetary value and to stimulate or enable money creation. The bank tends to be ambivalent and inconsistent in its regulatory actions.

${ }^{3}$ This would determine (1) what would be an appropriate aggregate level for given markets conditions for expansion or contraction; and (2) what level of money creation or destruction for each bank involved. Otherwise, there would be a probability of overshooting or undershooting what would be stabilizing levels. 
The multiple functions of money are referred to in economics textbooks when money is discussed. What is typically not discussed is that the functions or purposes of money are contradictory [2] [3]. Policy and regulative efforts to deal with issues relating to one money purpose often undermines or blocks dealing with issues relating to other purposes: for instance, monetary value stability is potentially in contention with capital formation and socio-economic development, hence, the dilemmas of the Federal Reserve Board for much of its history [3].

Monetary value stability may be achieved at the expense of investment and growth; or, investment and growth may be achieved at the expense of unstable money values such as inflation. Or, attempts to deal with the use of money for speculation may hamstring consideration of encouraging capital formation and deployment.

\section{What Then? New Designs and Institutional Arrangements}

On the basis of our research and that of others, we concluded that there are at least two fundamental problems to solve in developing a new design and institutional arrangement:

(1) Solve the coordination problem by having centralized, legally enforced money creation (regulation of the credit creation of individual banks and the aggregate effects), thus eliminating uncoordinated money creation and contraction as occurs in the existing banking system.

(2) Differentiate and regulate the contradictory functions or purposes of money, for instance, money as a medium of exchange; money as a store of value; money as capital, an instrument of investment and economic development; money utilized for speculative purposes, among other "functions."

\subsection{Solving Coordination Problems (CAPs) in Money and Financial Systems}

The lack of coordination in credit/money creation and credit/money destruction is a type of collective action problem (CAP). The behavioral phenomenon is well-known in the social sciences (CAPs entail "collective responses to possibilities of bonanza", on the one hand, and collective responses to "fire-in-the theatre", on the other; CAPs share characteristics with n-person prisoners' dilemma game [2] [12]. Rapid contraction under conditions of no coordination (of exit actions) combined with contagion results in panic behaviour, a form of collective action problem as in the fire-in-the-theatre panic where the efforts to escape the burning theatre are not coordinated or organized [12]. Multiple, uncoordinated, autonomous agents respond typically to possibilities of large gains or, conversely, the threat of major losses-by racing to get in-or alternatively, racing to get out-in the absence of a normative or social organizational order. The population of autonomous agents generate uncoordinated and destabilizing market behavior, associated with "bubble formation" as well as "bubble collapse" with respect to particular asset markets and productive sectors: whether real es- 
tate, equities, financial instruments such as derivatives, and hedge funds, or Dutch tulips, ${ }^{4}$ South Sea "pie-in-the sky", and so on [4].

More generally, we suggest that the deep explanation of banking and financial crises lies in the key freedoms and power processes to create credit (that is, a form of money creation) which together with innovation capabilities tends to result in over-expansion and the generation of high risk prone and vulnerable systems. The key mechanisms of over-expansive credit-creation (e.g., through diverse and innovative forms of leveraging) but also of protective contraction (e.g., de-leveraging typically entails crowd-type behavior-imitation and diffusion of self-fulfilling beliefs), generate uncoordinated and destabilizing market behavior.

Following the 1929 Crash, proposals for new institutional design(s) of money and banking emerged. Among these, the Chicago Plan (1935)—much discussed and debated at the time but with limited influence on the reforms of the 1930s [13] [14]. The Chicago Plan-and related proposals-were taken up again after the 2007+ Crash [9]. The Plan eliminated money creation (credit creation) on the part of private banks. Only the state central bank could create money (and this according to a money creation principle or rule complex/algorithm for money creation). Commercial banks could only lend what available in savings accounts for investment purposes (what is referred to as full reserve banking; there would be no fractional banking). The money deposited in a bank in current or transaction as well as pure savings accounts could not be used for making loans.

Solving money market CAPs could be accomplished by the Central Bank creating all new money and feeding it into the economy through at least one of four mechanisms (cf. van Egmond and deVries [15]): ${ }^{5}$ There could be at least four ways to introduce new central bank money: (a) The Central Bank can create new money to lend to commercial banks, which would allocate the money in new loans; that is, respond to market demand in their locality; (b) through money creation, the government can provide subsidies to citizens, or groups of companies, for purposes of stimulating consumption and/or investment; (c) the government could also reduce the taxes of citizens, manufacturers, and other businesses [(b) and (c) are ways to stimulate demand in the economy and economic growth]; (d) governmental newly created money may be invested in government projects; the development of infrastructure, built environments, etc.

\footnotetext{
${ }^{4}$ The supply of money increased dramatically in the 1630s Holland, serving to engender the tulipmania episode. The price of tulips only served as a manifestation of the end result of a government policy that expanded the quantity of money and thus fostered an environment for speculation and malinvestment. The Dutch Tulip madness involved people using their own resources, but also borrowing money and mobilizing money in other ways. However, they did not just harm themselves, they harmed others and the society which could have made better use of the resources mobilized and wasted. That judgment applies to the 1929 and $2007+$ crashes as well as numerous other crashes.

${ }^{5} \mathrm{~A}$ 2nd more decentralized way would be for the central bank to allocate credit/money creation rights of certain amounts to each and every bank under its perusal. This would be done on the basis of the bank's size and previous performance. The banks could only create money to the degree designated by the Central Bank according to its allocation principle or algorithm.
} 
In sum, under a Chicago or similar institutional design, the Central Bank creates and puts into circulation money in the money and financial system through subsidies, tax reductions, and government expenditures as well as government loans with interest to commercial banks. As Van Egmond and De Vries [15] suggest, the money inputs into the financial-economic system tend to stimulate the real economy: “... it's a political choice to maintain or to increase the amount of money creation. In all cases the Keynesian stimulation of the economy can be far more effective than by means of interest rates only ... the choice for inflation (and also deflation) is a political one .... This model experiments show that money creation by the government, according to a 'model creation rule' which is directed to price stability and/or employment, indeed can stabilize the boom-bust cycles that occur in the present money and financial system."

Benes and Kumhof [9] investigated and found through their simulation studies support for Irving Fisher's [13] claims that the Chicago Plan had the following advantages (also see van Egmond and de Vries [15]):

(1) Much better control of a major source of business cycle fluctuations, sudden increases and contractions of bank credit and of the supply of bank-created money.

(2) Complete elimination of bank runs.

(3) Dramatic reduction of the (net) public debt.

(4) Dramatic reduction of private debt, as money creation no longer requires simultaneous debt creation. Furthermore, output gains were found to approach 10 percent, and steady state inflation could drop to zero without posing problems for the conduct of monetary policy.

\subsection{Solving Regulatory Problems Arising from the Multiple, Contradictory Functions/Purposes of Money}

Here we focus on the multiple contradictory functions or purposes of money and suggest possible institutional arrangements for differentially regulating money functions. For example, Money I as a Medium of exchange, Money II as a store of value, Money III for the purpose of capital formation and financing project initiatives and development, and Money IV for purposes of speculation, which should be banned or highly constrained.

The diverse functionalities of money should be distinguished cognitively/categorically as well as institutionally. This corresponds to what Viviana Zelizer refers to as "earmarking" on the family and organizational level [16]. The types/categories of money would be differentiated by special banks, accounts, and regulatory regimes, as already suggested in the categorization of money types, their specific purposes, and regulatory logics: money Type I is for economic agents to use in market exchange and everyday transactions; Type II is savings money to be kept in accounts for future use. Type III is designated for capital formation and investment; it is provided by individuals, businesses, public agencies, and the central bank for purposes of investment and development. Finally, Type IV money used for speculative purpose would be banned or heavily 
constrained in brief.

\subsubsection{Money I as a Medium of Exchange}

There will need to be institutional arrangements to assure sufficient money in circulation. Certain "Banks" would maintain current accounts-for households, businesses, etc.-payments are drawn on accounts and payments are made into them. There would need to be some buffering mechanisms to deal with time and balance issues. Mechanisms for expanding currency in circulation and/or its velocity would be required. The purpose and regulatory framework for this type of money is kept distinct from money in savings or money-as-capital (as today in the distinction between current and savings accounts).

\subsubsection{Money II as a Store of Value}

The purpose of Money II is savings: either to keep for future use and/or earn interest. Savings can be placed in special "banks", an institutional arrangement where depositors receive interest for their deposits, a rate decided by the central bank. Through setting the interest rate, the Sovereign can encourage savings or dis-savings. But pure savings banks would not loan money. Of course, the central bank's payment of interest would be based on its budget resources and/or money creation.

The stability of money value is important both for money as a medium of exchange and as a store of value. Money as a unit of accounting-conveys information through a system of prices. Money expressed in prices enables comparisons of commodities in a complex system.

\subsubsection{Money III for the Purpose of Loans and Financing Project Initiatives and Development}

This "money" would be mediated through banks obtaining money for this purpose-the money would come from individuals, households, companies, municipalities wishing to earn more than they can earn through "savings associations" (Money II); these actors and the banks would be risk-takers; these investments would be secured to varying degrees by private and/or public insurance schemes, or by some degree of Sovereign guarantees. It would make sense to have specialized investment banks as earlier ("home loan", "agriculture," "international trade," "venture capital investors", etc.), whose levels of risk would likely vary considerably.

Financial capital may be "invested" in economic activities to facilitate the expanded production of goods and services by oneself or by others to whom one loans capital. Investing money to gain more money, the value of the original (level of) money is significantly-exponentially-greater than the value of the money that is not (available) to be exchanged in this way. For instance, just used for the purchase of commodities.

Financial capital in a "genuine market" for investment (stocks, shares, bonds, projects, etc.) is, of course, a productive power or force for development. Those who "specialize" (focus) on the accumulation and investment of financial capital 
play a crucial role in fueling economic growth that is essential to creating wealth.

The "sovereign" could supplement the capital of Money III banks with money creation for risk purposes. They would be in a position to precisely steer these developments, for instance, by creating money for Money III banks operating in priority areas, such as renewable energy, sustainable technology developments, medical research and development, etc. The money III creation legitimized by the state could be either in the form of subsidies and/or loans.

Of course, the policies and rules concerning Money III creation as well as provision of loans would need to be spelled out; there would be a distinct rule regime regulating type III money formation and disposition. This would not be arbitrary money creation (a la Argentina). Moreover, the Sovereign would be in a position to regulate the degree of risk-taking (from $100 \%$ to $0 \%$ ).

\subsubsection{Money IV for Purposes of Speculation}

For instance, with respect to stocks, bonds, and money exchange markets themselves-should be banned, if possible, or at least heavily penalized and/or taxed. In a world of electronic banking, increased systematic and effective constraints on "casino economy" practices should be feasible. ${ }^{6}$

The very rich have monetary resources with which to play speculative games. Moreover, they are in a better position than most to obtain credit-for their speculations-which doubly takes resources away from other, more essential uses. Cutting back on resources used in speculation would free these resources for productive uses. To the extent that advanced economies already put excessive resources into financial (and all-too-often speculative) dealings, and these resources are needed for innovation and development of such areas as alternative energy and transportation development, health care, etc.

As suggested in the article, banning may not be feasible. But constraints can be imposed. This is the point of the "Tobin Tax" and its several variants such as the financial transaction tax or the securities transaction tax.

Besides taxation and penalties, certain sectors should be excluded; other constraints could be that no borrowed money would be allowed (easy enough in the Chicago Plan since the Central Bank may specify and provide new money for appropriate investment sectors); time constraints against short-term transactions-not only a tax or penalty but time rules. In general, an elaborate policy regime is needed to constrain, if not partially eliminate, speculation (and the access of speculators to money resources).

Keynes proposed in 1936 a transaction tax to be levied on dealings on Wall Street, where he argued that excessive speculation by uninformed financial traders increased volatility. For Keynes (he was himself a speculator) the key issue was the proportion of "speculators" in the market, and his concern that, if left unchecked, these types of players would become too dominant! This is, in part, a correct assessment, in part because of the rapid accumulation of wealth; in part

\footnotetext{
${ }^{6}$ Monetary authorities have developed analytic frameworks and other tools to identify and penalize money laundering schemes. A similar cognitive, normative and regulative development should be achievable in the case of speculation. Of course, ambiguous and fuzzy cases will certainly occur.
} 
because Wall Street becomes a hot spot attracting others interested in speculating with some resources at their disposal including bank loans.

The original Tobin tax proposal (early 1970s) was intended to put a penalty on short-term financial round-trip excursions into another currency. His intent was "to dissuade speculators". By the late 1990s, however, the term Tobin tax was being incorrectly used to describe all forms of short term transaction taxation, whether across currencies or not. Tobin's method of "throwing sand in the wheels" was to suggest a tax on all spot conversions of one currency into another, proportional to the size of the transaction. In the development of his idea, Tobin was influenced by the earlier work of Keynes of general financial transaction taxes. Keynes proposed in 1936 that a transaction tax should be levied on dealings on Wall Street, where he argued that excessive speculation by uninformed financial traders increased volatility. For Keynes (who was himself a speculator) the key issue was the proportion of "speculators" in the market, and his concern that, if left unchecked, these types of players would become too dominant.

\section{Powerful Political/Socio-Cultural Constraints on Any Major Financial Reform}

Repeated attempts to constrain and regulate the uses and abuses of bank powers of credit creation and allocation have only succeeded partially, in spite of a long history of trying; there was partial success in the 1930s with the establishment of a complex of bank and financial regulatory arrangements [17]. ${ }^{7}$ But "the New Financial Arrangements" (NFA) established in the 1970s and 1980s eroded much of the very limited reforms of the 1930s. Thus, the New Deal arrangements for bank regulation were reversed through a sustained counter-attack of neo-liberalism forces to dismantle the New Deal framework. These developments reflected the parallel ideological and institutional struggles that established neoliberalism and the principle of the supremacy of the market and its agents, in particular their capacity to fully self-regulate and self-equilibrate [18]. ${ }^{8}$

Part of the problem is that banks are not only serving important societal functions, which policymakers and multiple stakeholders support, but that many of them are also economically and politically powerful with their own private interests and substantial capacities to influence and manipulate policies and the architecture of regulation [19]. Moreover, banks in a capitalist system are capable of major innovations in their strategies, products and procedures-often in ways to circumvent the regulations to which they are subject. For instance,

\footnotetext{
${ }^{7}$ In the USA, among others, the Glass-Steagall Act of 1933, the 1956 Douglas Amendment, the Investment Company Act of 1940, the Investment Advisory Act of 1940, the Commodity Exchange Act of 1936, the Security and Exchange Act of 1934 (with the 1963 Amendments) [20].

${ }^{8}$ Neo-liberalism - the godfather of the high risk banking and financial system that led up to the 2007 Crash-was no emergent (or "invisible hand") phenomenon. There were powerful, purposive agents who initiated and established it. During the early period of the Cold War, a movement led by business interests and associated intellectuals worked to create a better climate for business and the wealthy in the USA (indeed, the "cold war" provided a context for stressing the importance of capitalism and the business community).
} 
hedge funds and private equity funds were designed to rely on exemptions from the US Investment Company Act of 1940 and the Investment Advisory Act of 1940 (this was accomplished mainly through avoidance of public offerings (and the greater transparency that such offerings would provide)) to avoid being subject to the demands of these statutes [17].

Neo-liberalism - the godfather of the high risk banking and financial system that led up to the 2007 Crash-was no emergent (or "invisible hand") phenomenon. There were powerful, purposive agents who initiated and established it. During the early period of the Cold War, a movement led by business interests and associated intellectuals worked to create a better climate for business and the wealthy in the USA (indeed, the "cold war" provided a context for stressing the importance of capitalism and the business community) [20].

Neoliberal ideologues attacked "excessive regulation," claiming that it was blocking innovation and economic growth. Many of the problems in the 1970s, for example, the phenomenon of stagflation, were blamed on government regulation and excessive government intervention. (All of this were taking place in the context of 1968, the Vietnam War, massive global demonstrations, and open radical movements in many countries.) This set the stage for the construction of new financial and regulatory conditions, the so-called New Financial Arrangements (NFA). ${ }^{9}$

In the period from the 1970s to the 2000s, the restructuring and transformation of the banking and financial system entailed, among other things, the removal or rewriting of the 1930 laws and policies and the introduction of new ones.

The growing ideology of neoliberalism, the range of technological innovations-some of them enabling avoidance of regulation-and, in general, the overall powers of the financial industry resulted in conditions where regulatory arrangements were increasingly inadequate to deal with the risky financial systems which emerged in the 1970s and afterwards. The neoliberal framework and its principles convinced regulators that agents in the financial markets were much more competent than themselves and were fully capable of dealing with any major risks and market instabilities. Regulators admired and trusted the industry's technical skills displayed in quantitative risk models of financial agents and the industry, which enabled them to price and manage risk better than earlier and better than the regulators could ever manage [17]. Wray ([21], 815) points out:

... innovations ... had already undermined New Deal restraints while others were apparently pushed through by administration officials with strong ties to financial institutions that would benefit (from the changes, our addition). Whatever the case, these changes allowed for greater leverage ratios

\footnotetext{
${ }^{9}$ As Stiglitz [2] points out, "The regulatory structure did not keep up with changes in the financial system ... The international banking regulatory structures (such as Basle II) were based on the normative idea of self-regulation ...." The prevailing deregulatory philosophy influenced those appointed to enforce regulation [22].
} 
(in some cases reaching 20 to 30 times capital), riskier practices, greater opacity, less oversight and regulation, consolidation of power in "too big to fail" financial institutions that operates across the financial services spectrum (combining commercial bank, investment banking and insurance and greater risk ... No one captured the reigning sentiment better (or played a bigger role in the deregulation movement) than Chairman Greenspan: "Market participants usually have strong incentives to monitor and control the risks they assume in choosing to deal with particular counterparties ... Private regulation generally is far better at constraining risk taking than is government regulation. In other words, the state would take a step back and let 'free markets' regulate themselves." [23].

The overall deregulatory thrust launched during the 1970s and developing more or less "hegemonically" until 2007 facilitated, among other things, major increases in credit expansion and leverage extremes. Increased leverage, motivated by higher bank profits, significantly increased basic vulnerability to default at the same time. The very substantial profits were not used to reinforce banks' capital base and solidity in a context of increasing stakes. The FRB under Greenspan operated more or less unconcerned with asset "price inflation" and focused instead on domestic US consumer price inflation which remained low largely due to cheap Chinese imports [24].

In general, during this period the normative climate was lax: macro-, meso-, and micro norms of prudence, and risk adversity were weakened or ignored. The general atmosphere became permissive and risk insensitive, embodoed in the attitude and policies of Alan Greenspan as Chairman of the US Federal Reserve Board, his statements and policies reinforcing the "lax climate". For long periods, FRB policy was to maintain very low interest rates, basically interest-free loans if one corrected for inflation, and at the same time to step in to rescue those suffering major failures during the 1980 and 90s (in the period from 1986 to 1995 more than 1000 (of 3200+) savings and loans banks failed) and early the late 1990 and early 2000s (when the doc.com or tech bubble burst, the NASDAQ fell as much as $78 \%){ }^{10}$

In sum, interest-based power relations, hegemonic cognitive framework of neo-liberalism (along with substantial theoretical and practical expertise), ${ }^{11}$ pressure-group politics (with lobbyists, associations, think-tank pundits), and the systemic functional power of financial systems and agents; control over a strategic/key area in the contemporary world such as banking and finance makes

\footnotetext{
${ }^{10}$ The bubble consisted of a combination of rapidly increasing stock prices, market confidence that the information-technology companies would turn future profits, market speculation in stocks, and widely available credit for venture capital created an environment in which many investors were willing to overlook traditional metrics, such as the price-to-earnings ratio (P/E ratio). By the end of the 1990s, the NASDAQ hit a P/E ratio of 200, a truly astonishing plateau that dwarfed Japan's peak $\mathrm{P} / \mathrm{E}$ ratio of 80 a decade earlier. The collapse of the bubble took place during 1999-2001. Many companies failed completely, others saw stocks decline by $50 \%-60 \%-70 \%-80 \%$.

${ }^{11}$ The framework of neo-liberal economic theory of the self-correcting, self-regulating markets according to which markets are capable of restoring equilibrium whenever internal or external forces disturb them.
} 
for a high capacity to influence strategic decisions and policies as well as institutional designs (there is very limited countervailing power and expertise from the state as well as civil society and NGOs-under the influence of hegemonic neoliberalism). Global finance had become the key actor and the prosperity itself of the 1990s for developd countries derived to a great extent from a global growth of public and private finance and credit, facilitated by substantial deregulation and justified by neo-liberal economic doctrine.

Given the continued powerful counterforces and constraints on redesigning and establishing new systems of money and finance-limited success in the 1930s and little success in the aftermath of the 2007 crisis at the same time the potentially highly unstable system continues to operate-it would be useful to discuss "what next", "what is possible"? We see an immediate challenge, a need to systematically-with theoretical, empirical, and policy research-counter the ideology that markets are basically self-regulating and equilibrating. It is widely recognized that most markets of any complexity and/or with complex products are highly regulated: legal arrangements, effective judiciary processes, safety-ofproduct regulations, occupational safety and labor force regulations, capital markets and banking regulation, regulation against deception and fraud, etc. Capitalist markets need state regulation-in order to minimize market failures, market conflicts and movements disrupting markets and the economy as a whole [25]. On the other hand, national government policies may become an obstacle to the development of global markets, they increase transaction costs, and they threaten the free circulation of people, capital flows, good and services.

In light of these considerations, a task force (or a network of taskforces) should consider some elaborated form of "embedded and regulated capitalism", similar but not equal to the regime prevailing in post-Second World War decades, prior to many of the Neo-liberal reforms including the New Financial Arrangements (NFA). Moreover, such taskforce(s) should proactively prepare for the next serious crisis when reform packages, which has been thought out and formulated earlier can be introduced and discussed. The tasks force(s) would be encouraged to prepare a knowledge base and models, mobilizing expertise and publishing "plans" or reports-at this time there is already considerable knowledge production of alternatives such as the Chicago Plan. It is essential to involve not only multi-disciplinary researchers but policymakers and practitioners in these preparatory deliberations and analyses. ${ }^{12}$

\section{Conclusion}

The paper concludes that reform is necessary-if boom-and-bust cycles on the scale of those since 1929 are to be effectively regulated. One or more new alter-

${ }^{12}$ This was done in preparation for eventual EU food crises and the necessity of establishing new governance and regulatory arrangements in the EU [26]. Already, some in the EU Commission had anticipated problems-of hazard and security-prior to the food scandals in the 1990s, but could not gain support for introducing a new regulatory framework which had been prepared. Once the "mad cow disease" (particularly with British beef), and Belgium chickens with dioxin-and threats of boycotts and blockage of the single market-the regulatory framework-in-waiting could be introduced and put into place. 
native designs such as the Chicago Plan-or variants of it-should be developed into proposals for consideration whenever the opportunity for radical reform affords itself (for instance, a new crisis or the election of a reform government with a major mandate). However, in the short-run such reform is politically and ideologically difficult if not impossible. In the meantime, alternative system designs and institutional arrangements must be investigated and debated.

\section{Acknowledgements}

We are grateful to Helena Flam and Joc Pixley for their comments and suggestions on an earlier version of this article.

\section{References}

[1] Burns, T.R., Martinelli, A. and DeVille, P. (2013) A Socioeconomic Systems Model of the Global Financial Crisis of 2007+: Power, Innovation, Ideology, and Regulatory Failures. In: Pixley, J. and Harcourt, G., Eds., Financial Crises and the Nature of Capitalist Money, Palgrave Macmillan, London, 216-248. https://doi.org/10.1057/9781137302953_13

[2] Burns, T.R. and DeVille, P. (2003) With the Three Faces of the Coin: A Socio-Economic Approach to the Institution of Money. European Journal of Economic and Social Systems, 16, 149-195.

[3] DeVille, P. and Burns, T.R. (1976) Institutional Response to Crisis in Capitalist Development. Social Praxis, 4, 5-46.

[4] Kindleberger, C. and Aliber, R. (2005) Manias, Panics and Crashes: A History of Financial Crises. Palgrave Macmillan, London. https://doi.org/10.1057/9780230628045

[5] Minsky, H. (1977) A Theory of Systemic Fragility. In: Altman, E.D. and Sametz, A.W., Eds., Chapter 6: Financial Crises. Institutions and Markets in a Fragile Environment, John Wiley and Sons, New York, NY, 138-152.

[6] Minsky, H. (1982) Can "It" Happen Again? Essays on Instability and Finance, M.E. Sharpe Publisher, New York.

[7] Burns, T.R. and Gomolinska, A. (2001) Socio-Cognitive Mechanisms of Belief Change Applications of Generalized Game Theory to Belief Revision, Social Fabrication, and Self-Fulfilling Prophesy. Cognitive Systems Research, 2, 39-54.

[8] Aikman, D., Haldane, A. and Nelson, B. (2010) Curbing the Credit Cycle. Presented at the Conference on Micro-Foundations for Modern Macroeconomics, New York, November 2010.

[9] Alessandri, P. and Haldane, A.G. (2009) Banking on the State. Presented at the Federal Reserve Bank of Chicago Twelfth Annual International Banking Conference.

[10] Benes, J. and Kumhof, M. (2012) The Chicago Plan Revisited. IMF Working Paper 12/202, IMF, Washington, D.C.

[11] Dudlev, W. (2010) Asset Bubbles and the Implications for Central Bank Policy. Federal Reserve Bank of N.Y. http://www.newyorkfed.org/newsevents/speeches

[12] Buckley, W., Burns, T.R. and Meeker, D. (1974) Structural Resolutions of Collective Action Problems. Behavioral Science, 19, 277-297.

https://doi.org/10.1002/bs.3830190502

[13] Fisher, I. (1935) 100\% Money: Designed to Keep Checking Banks 100\% Liquid; to Prevent Inflation and Deflation; Largely to Cure or Prevent Depressions; and to 
Wipe out Much of the National Debt. The Adelphi Company, New York.

[14] Phillips, R. (1994) The Chicago Plan \& New Deal Banking Reform, M.E. Sharpe.

[15] van Egmond, N.D. and de Vries, B.J.M. (2015) Dynamics of a Sustainable FinancialEconomic System. Working Paper of the Sustainable Finance Lab. Utrecht University, The Netherlands.

[16] Zelizer, V.A. (1997) The Social Meaning of Money. Princeton University Press, Princeton.

[17] Ghilarducci, T., Nell, E., Mittnik, S., Platen, E., Semler, W. and Chappe, R. (2009) Meorandum on a New Financial Architecture and New Regulations. Investigación Económica, LXVIII, 147-161.

[18] Crotty, J. (2009) Structural Causes of the Global Financial Crisis: A Critical Assessment of the "New Financial Architecture". Cambridge Journal of Economics, 33, 563-580. https://doi.org/10.1093/cje/bep023

[19] Alberto, M. (2007) Transatlantic Divide. Comparing American and European Society. Oxford University Press, Oxford.

[20] Burns, T.R., Martinelli, A. and DeVille, P. (2011) The Global Financial Crisis of 2007+: Ideology, Meta-Power, Systemic Risks, and Regulatory Failures-A SocioEconomic Systems Model. Presented at the European Sociological Association Congress, Geneva, September 2011. Earlier versions of this work were presented at the European Sociological Association Congress, Lisbon, September 2009 and at the CERES 21 Workshop, Dubrovnik, September, 2010.

[21] Wray, L.R. (2009) The Rise and Fall of Money Manager Capitalism: A Minskian Approach. Cambridge Journal of Economics, 33, 807-828.

[22] Stiglitz, J. (2011) Principles for a New Financial Architecture. The Commission of Experts of the President of the UN General Assembly on Reforms of the International Monetary and Financial System, New York.

[23] Ferguson, T. and Johnson, R. (2009) Too Big to Bail: The "Paulson Put", Presidential Politics and the Global Financial Meltdown, Part I: From Shadow Financial System to Shadow Bailout. International Journal of Political Economy, 38, 3-34. https://doi.org/10.2753/IJP0891-1916380101

[24] Ingham, G. (2011) Capitalism. Polity, Cambridge.

[25] Burns, T.R. and DeVille, P. (2007) Dynamic Systems Theory. In: Bryant, C.D. and Peck, D.L., Eds., The Handbook of 21 st Century Sociology, Sage Publications, Thousand Oaks, CA, 569-582. https://doi.org/10.4135/9781412939645.n57

[26] Carson, M., Burns, T.R. and Calvo, D. (2009) Public Policy Paradigms: Theory and Practice of Paradigm Shifts in the European Union. Peter Lang, Frankfurt/New York/Oxford. 
Submit or recommend next manuscript to SCIRP and we will provide best service for you:

Accepting pre-submission inquiries through Email, Facebook, LinkedIn, Twitter, etc. A wide selection of journals (inclusive of 9 subjects, more than 200 journals)

Providing 24-hour high-quality service

User-friendly online submission system

Fair and swift peer-review system

Efficient typesetting and proofreading procedure

Display of the result of downloads and visits, as well as the number of cited articles Maximum dissemination of your research work

Submit your manuscript at: http://papersubmission.scirp.org/

Or contact tel@scirp.org 